\title{
Practices of community representatives in exploiting information channels for citizen democratic engagement
}

\author{
Hazel Hall, Peter Cruickshank, Bruce Ryan \\ Edinburgh Napier University, Edinburgh, UK
}

\begin{abstract}
The purpose of the research was to investigate the practices of elected, yet unpaid, community councillors in Scotland as they exploit information channels for democratic engagement with citizens. Its focus is both novel and significant in that it considers the information literacy of a group that has not been studied before: volunteer representatives active in hyperlocal government. The primary means of data collection was semi-structured interviews of one hour in length with 19 community councillors. Research design and data analysis were informed by the SCONUL 7 pillar model of information literacy, and by Activity Theory. The main finding of the analysis is that community councillors engage with a range of information sources and tools in their work, the most important of which derives from local authorities. Three recommendations emerge from the analysis. These relate to (i) information literacy training; (ii) valuing information skills; and (iii) the role of the public library service in supporting community council work.
\end{abstract}

\section{Keywords}

Community councillors, hyperlocal representatives, democracy, information literacy

\section{Introduction}

The research findings reported in this paper relate to an investigation into the information practices of those engaged in democratic processes as community-level elected representatives in Scotland: community councillors. Entitled Information Literacy for Democratic Engagement (IL-DEM), the study was funded by the Information Literacy Group (ILG) of the UK Chartered Institute of Library and Information Professionals (CILIP).

The broad aim of IL-DEM was to establish the current practices of community councillors in exploiting information channels for (i) learning about their roles and (ii) engaging citizens in democratic processes. This gave rise to three primary research questions:

- RQ1: How do community councillors access and understand information on their duties and rights?

- RQ2: How do community councillors keep up to date with local issues and developments of relevance to the communities that they serve?

- RQ3: How do community councillors disseminate information to their communities?

Three further questions were also addressed in this work:

- RQ4. Where do future efforts need to be directed to improve the information skills and practices of community councillors?

- RQ5. What are the roles of public library staff in the training of community councillors?
- RQ6. How do community councillors' information literacies contribute (i) to their communities, (ii) to building social capital, and (iii) to their or others' citizenships?

The SCONUL (2011) 7-pillar model of information literacy, along with Activity Theory (Engeström, 1987), informed research design that centred on the analysis of interview data collected in 2016.

The main finding of the analysis is that community councillors engage with a range of information sources and tools, the most important of which is local authority support as they fulfil their roles of accessing and sharing information between local communities and public authorities. Three recommendations were generated from this work. These relate to (i) information literacy training; (ii) valuing information skills; and (iii) the role of the public library service in supporting community council work.

Whereas information practices in government have previously been the subject of academic research in respect of service delivery (for example, Killick et al., 2016; Tait and Edwards, 2016), and the work of politicians (for example, Auty, 2005; Smith and Webster, 2004) and the information literacy of citizens (for example, Smith, 2016)

\section{Corresponding Author:}

Hazel Hall, Centre for Social Informatics, School of Computing, Edinburgh Napier University, 10 Colinton Road, Edinburgh EH10 5DT, UK

Email: h.hall@napier.ac.uk 
have also been explored in the past, this study is significant for its novel focus. It is the first piece of research to have considered the information literacy of volunteers active in hyperlocal government. As well as filling this gap in the literature, the findings will assist in the development of effective community councils in Scotland.

\section{Background}

\section{The research context: Scotland's community councils and community councillors}

Scotland's 32 local authorities were formed in 1975 to serve as the country's lowest tier of local government. The average population size within these local authorities is greater than 100,000 . This is a large number when compared with figures for local democracy in the rest of Europe (Mair, 2016). Therefore, at the same time that the new local authorities were established, community councils were introduced as a further level of 'hyperlocal' democracy. Part of the rationale behind the formation of community councils was to address fears of remoteness from the democratic process that citizens may have felt in the new local government structure (Goodlad et al., 1999).

Local authorities are responsible for defining their community councils' areas and numbers of members, for running community council elections, and for providing a limited amount of funding for their support. They publish mini-constitutions for community councils in documents known as 'schemes'. The schemes specify the roles and responsibilities of community councils, duties of paid office-bearers, and the running of meetings, as well as information sharing roles. When the research was carried out in late 2016 for the study reported here, twenty-five of the 32 local authorities made the schemes available on their web sites. (Twenty-seven were available online by July 2017.) Schemes can also be accessed through community council liaison officers who work in support of community councils as paid local government employees.

It should be noted that unlike most of Europe's democratic bodies, community councils are not bodies of government (Goodlad et al., 1999). They are conceived in legislation as representative bodies for particular geographic localities, and generally have no duties to deliver services, nor can they raise taxes, nor make regulations or laws. Their main role is explicitly centred on information sharing, with an emphasis on communicating local opinion to the higher tiers of local government. A community council has duties:

'to ascertain, co-ordinate and express to the local authorities for its area, and to public authorities, the views of the community which it represents, in relation to matters for which those authorities are responsible, and to take such action in the interests of that community as appears to it to be expedient and practicable' (UK Government, 1973)

Community councils also have a limited role in spatial planning. They may submit comments on, or objections to, planning applications both large (such as an industrial development) and small (for example change of use of a small shop to housing in a conservation area).

Currently there are approximately 1,100 active Scottish community councils. From this figure it is estimated that the total number of community councillors is of the order of 10,000 . Each community council's membership comprises voting members (elected and co-opted), and non-voting, ex-officio members (local authority councillors, members of the Scottish Parliament (MSPs), and members of the UK Parliament (MPs) whose wards and constituencies overlap the community council's area). Community councils may also appoint non-voting members from outside their geographical areas to provide extra skills, for example, IT/Internet communication skills.

The Scottish public library service made explicit its interest in the work of community councils in 2015 . The ambition of libraries was that they become the 'champions of community engagement' and 'creat[ing] partnerships with community planning partners' by supporting and training community councillors (SLIC, 2015).

The community council system in Scotland faces a number of challenges. The main problem is that it relies almost entirely on the voluntary efforts of community councillors, without any further funding for the hire of additional professional assistance (Bort, Mcalpine, and Morgan, 2012). As a result, many community councils struggle to fill their vacancies, community council elections often go uncontested, and community councils lack sufficient members to undertake all their tasks (Goodlad et al., 1999; Ryan and Cruickshank, 2012, 2014). For the same reason, in some parts of the country community councils do not exist at all (Cruickshank, Ryan and Smith, 2014; Goodlad et al., 1999; Ryan and Cruickshank, 2014).

The demographic profile of volunteer community councillors is also an issue, particularly in terms of information literacy. Many community councillors are older citizens, such as retired people who have the time to devote to voluntary work to support their communities. Many of these individuals have not benefited from formal information skills training over the course of their lifetime. Alternatively they may have enjoyed such training in the past, but now their information skills are out of date. This is reflected in the low numbers of community councils known to use the Internet to engage with, and/or obtain information from, their citizens, even though many citizens use the Internet to obtain information (Ryan and Cruickshank, 2014).

In addition, there are known barriers to effective information sharing in the community councillor role (Improvement Service, 2015). An implication of hyperlocality, for example, is that representatives often 
have unmediated and mixed channel interactions with the citizens they represent, with blurred (or collapsed) contexts (Davis and Jurgenson, 2014; Skoric et al., 2015). Such information flows are difficult to manage. For example, a conversation might begin at a formal meeting or in a chance encounter, then may be continued via social media, then again at the next community council meeting. This mode of interaction is more likely for hyperlocal representatives than for elected representatives in higher tiers of government, such as local authority councillors, MSPs, and MPs.

A fourth challenge is a degree of ambiguity around the role of community councils. This is exemplified by imprecise phrasing in the specifications of their roles, for example: 'in addition to any other purpose which [it] may pursue...' and 'to take such action in the interests of that community as appears to it to be expedient and practicable'. Thus, while it is clear that the main information sharing duty of community councillors is to transmit the views of local citizens upwards, official bodies (generally local authorities) often request community councils to share official information in the other direction.

\section{Literature review: a dearth of prior research into the information practices and skills of volunteer elected representatives}

Prior to embarking on the empirical work discussed below, literature related to the information practices and skills of volunteer elected representatives, with specific reference to information literacy, was sought for analysis.

It is over forty years since the publication of some of the earliest work on the value of information resources and information literacy in democratic decision-making. For example, a paper from the mid-1970s published in the Library Journal draws attention to the dangers of 'information illiterates' in democratic settings (Owens, 1976). Despite this, very little research of direct relevance to this study of volunteer community councillors is found in the extant literature.

There is, however, a stream of research on the information behaviours and use of paid government employees (for example, Killick et al., 2016; Tait and Edwards, 2016), and professional politicians (for example, Auty, 2005; Smith and Webster, 2004). This can be traced back to the late 1970s and early 1980s (for example, (Wilson and Streatfield, 1980; Wilson et al., 1979). This work is useful to set the context for studies such as that discussed in this paper, although it should be borne in mind that the position of community councillors as elected representatives differs from that of other groups - specifically government employees such as civil servants - in a number of respects. For example: elected representatives' 'employers' are the electorates of the constituencies that they serve; party-sponsored representatives generally take heed of party lines from both their regional and national organisations, while community councillors must be apolitical in their community council work; and community councillors are unpaid.

Recommendations are made for the standards of information literacy expected of government workers and policy makers in prior work. For example, in the context of the Finnish government, Kauhanen-Simanainen, (2005, p. 186) lists skills for: (i) handling information across a range of formats; (ii) disseminating information (for example, writing styles for online dissemination); and (iii) information retrieval (for example, abstracting, indexing and the deployment of metadata). Several of these requirements are relevant to the hyperlocal representatives in the study reported here because they engage with multiple information sources to complete their information sharing duties.

The nature of information behaviours and use in democratic processes is also considered in the prior work. For example, Tait and Edwards (2016) refer to information seeking as 'part of a collective activity shaped by the organisational culture which influences how individuals are able to engage with information sources'. They also refer to earlier work by Lloyd (2011) which advocates an understanding of information literacy as a set of practices. These points resonate with the position of bounded groupings of Scottish community councillors within community councils engaged in a range of activities to meet the requirements of their roles.

A broader consideration of the body of work on information seeking behaviours and use identifies a stream of research on workplace information literacy (much of which is authored by Lloyd, for example: Lloyd, 2007, 2011, 2013, 2017). Prior studies which match the context of the study reported in this paper (volunteer elective representatives in hyperlocal democracy) are scant, yet community councils 'work' (albeit unpaid) for their fellow citizens. Therefore previous articulations of workplace information literacy are considered as a valuable preface to the study discussed below. Those which introduce lifelong learning into considerations of workplace information literacy (for example, Irving et al., 2015) are also of value here, due to the general demographic profile of community councillors as detailed above.

Such prior research has identified a range of key skills related to: (i) searching for and locating information; (ii) evaluating information retrieved; (iii) managing information in the workplace in accordance with legislation; and (iv) keeping up to date with new information while coping with information overload (see, for example, Reedy et al., 2013 cited by Banek Zorica et al., 2014). The issue of the collective nature of information practices identified above in the literature on the information literacy of government workers is also brought to the fore in recent work on workplace information literacy in general. For example, Forster 
(2017c, p. 4) writes about its 'prominent inter-personal dimension', and notes that other researchers 'insist that workplace information literacy is strongly team-focussed' (Forster, 2017a, p. 14). He also refers to community discourse in his own definition of workplace information literacy (Forster, 2017a, p. 25). This situates workplace information literacy in communities which have common purposes and languages, linked to associated information systems, resources, services, and processes. Furthermore, citing the work of Goldstein and Whitworth (2017), Forster draws attention to the value of people (as opposed to texts) as key workplace information sources, and the need for an appreciation of the 'social and informal ways in which information is processed into knowledge' (Forster, 2017b, p. 34).

An understanding of the position of community councillors in Scottish democracy, combined with messages from the literature on information behaviour and use -related to prior studies of government workers and the ideals of workplace information literacy provided a platform from which to design a research project to investigate the current practices of community councillors in exploiting information channels for (i) learning about their roles and (ii) engaging citizens in democratic processes. The research approach taken is outlined in the section below.

\section{Methods}

The main data collection exercise for this project was a series of hour-long semi-structured interviews with community councillors. Four broad interview themes, that were used to draft the interview questions, were initially generated from the six research questions noted above. These were: 'information literacy, behaviour and practices'; 'lifelong learning/everyday life'; 'libraries'; 'communities, social capital and citizenship'. 'Becoming information literate' was also added to these themes because (i) some information literacy definitions, such as that of the American Library Association (2000), make reference to this, and (ii) there was an interest in understanding the means by which community councillors develop the information literacy that supports their activities. The findings from the literature review completed at the start of the project also contributed to question design.

The interview questions were then validated against the SCONUL 7-pillar model of information literacy (2011), devised initially for use in higher education settings (see Figure 1). The SCONUL model was selected for this purpose on the basis of its recency and extensibility, as noted by Secker et al. (2016).

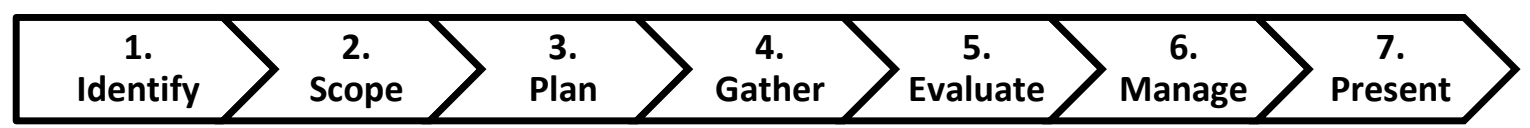

Figure 1. The SCONUL 7-pillar model of Information Literacy

While the further development of the SCONUL core model was not an aim of this project - rather it was deployed to ensure that the data collected would be comprehensive enough for an analysis to answer the project's research questions - it was attractive as a starting point for research design in this work because it has been adapted in the past to include 'lenses' for contexts other than higher education. These include: graduate employability (Goldstein, 2015; SCONUL, 2015); digital literacy (SCONUL, n.d.); open content/open educational resources (SCONUL, 2016); research (Bent and Stubbings, 2011); and evidencebased practice healthcare (Dalton, 2013).
Given the collective, collaborative and/or social nature of workplace information activities (Kauhanen-Simanainen, 2005; Tait and Edwards, 2016), and in recognition that the information practices of individual community councillors are enacted within groups, the interview questions were also validated against the constructs of Activity Theory (Engeström, 1987). An account of the use of Activity Theory in research on information behaviour and use in general, and its application in the project reported here, is available in another publication generated from the ILDEM project (Hall et al., 2017 in press).Sample interview questions and their correspondence to the research questions are given in Table 1. 
Table 1: Research questions and sample interview questions

\begin{tabular}{|c|c|c|c|}
\hline $\begin{array}{l}\text { Research } \\
\text { question }\end{array}$ & Sample interview questions & Research theme & $\begin{array}{l}\text { Number of } \\
\text { interview } \\
\text { questions* }\end{array}$ \\
\hline RQ1 & $\begin{array}{l}\text { How do you go about finding information about your } \\
\text { duties and rights? What sources do you use? How did } \\
\text { you learn about them? }\end{array}$ & SCONUL pillars 3 and 4 & 7 \\
\hline \multirow[t]{2}{*}{ RQ2 } & $\begin{array}{l}\text { Do you consciously think about the information that you } \\
\text { need to gather about local issues and developments? }\end{array}$ & SCONUL pillars 1 and 2 & \multirow[t]{2}{*}{6} \\
\hline & $\begin{array}{l}\text { How do you work out if the information that you find is } \\
\text { any good? }\end{array}$ & SCONUL pillar 5 & \\
\hline RQ3 & $\begin{array}{l}\text { How do you go about sharing information with your } \\
\text { community? }\end{array}$ & SCONUL pillars 6 and 7 & 5 \\
\hline RQ4 & $\begin{array}{l}\text { Do your other roles in life (such as parent, grandparent, } \\
\text { child, friend, colleague, boss, organisation-member, } \\
\text { volunteer) help you in finding information for your } \\
\text { community council work? If so how? What are they? } \\
\text { What help have you had from Local Authorities in finding } \\
\text { information (or learning how to find it)? }\end{array}$ & $\begin{array}{l}\text { becoming information } \\
\text { literate } \\
\text { lifelong } \\
\text { learning/everyday life } \\
\text { communities, social } \\
\text { capital and citizenship }\end{array}$ & 8 \\
\hline RQ5 & $\begin{array}{l}\text { What help have you had from libraries in finding } \\
\text { information (or learning how to find it)? }\end{array}$ & $\begin{array}{l}\text { SCONUL pillar } 4 \\
\text { libraries }\end{array}$ & 2 \\
\hline RQ6 & $\begin{array}{l}\text { Can you give an example of the importance or use of } \\
\text { information skills to support citizenships, civil rights or } \\
\text { social capital? }\end{array}$ & $\begin{array}{l}\text { communities, social } \\
\text { capital and citizenship }\end{array}$ & 3 \\
\hline
\end{tabular}

* Some interview questions covered more than one research question.

The full interview schedule was piloted with staff of the Improvement Service (the national improvement service for local government in Scotland), then implemented in November and December 2016 with 19 representatives from 17 community councils, situated in 8 of Scotland's 32 local authorities. The 19, as listed in Table 2, came from a pool of volunteers who responded positively to calls for participation that were communicated on an online discussion board for community councillors, and the national community council web site. Community council liaison officers also assisted in recruitment. The selection of data subjects ensured that a range of community council areas across Scotland was represented, from remote rural to highly urban, and well-off to highlydeprived.

Table 2: Community councillor participants in the IL-DEM project

\begin{tabular}{|l|l|l|l|l|l|l|}
\hline$\#$ & Years of service & Age band & Gender & Highest level of qualification (years held) & Location & SIMD \\
\hline 1 & 4 & $40 \mathrm{~s}$ & $\mathrm{M}$ & Masters (15) & Very urban & 9 \\
\hline 2 & 5 & $50 \mathrm{~s}$ & $\mathrm{~F}$ & Degree (15) & Very urban & 10 \\
\hline 3 & 6 & $50 \mathrm{~s}$ & $\mathrm{M}$ & Masters (30) & Very urban & 10 \\
\hline 4 & 17 & $50 \mathrm{~s}$ & $\mathrm{~F}$ & Degree (20) & Very urban & 10 \\
\hline 5 & 3 & $60 \mathrm{~s}$ & $\mathrm{M}$ & Degree (40) & Small urban & 9 \\
\hline 6 & 2 & $40 \mathrm{~s}$ & $\mathrm{M}$ & Degree (5) & Small urban & 6 \\
\hline 7 & $<1$ & $50 \mathrm{~s}$ & $\mathrm{M}$ & Masters (26) & Rural & 7 \\
\hline 8 & 3 & $40 \mathrm{~s}$ & $\mathrm{~F}$ & Masters (20) & Rural & 8 \\
\hline 9 & 3 & $50 \mathrm{~s}$ & $\mathrm{~F}$ & PG Dip (26) & Very urban & 6 \\
\hline 10 & 4 & $50 \mathrm{~s}$ & $\mathrm{~F}$ & Diploma (5) & Rural & 6 \\
\hline 11 & 15 & $70+$ & $\mathrm{M}$ & Masters (33) & Small urban & 7 \\
\hline 12 & 1 & $60 \mathrm{~s}$ & $\mathrm{~F}$ & Masters (15) & Rural & 7 \\
\hline 13 & 2 & $70+$ & $\mathrm{F}$ & Masters (21) & Very rural & 6 \\
\hline 14 & $<1$ & $50 \mathrm{~s}$ & $\mathrm{~F}$ & Degree (20) & Small urban & 7 \\
\hline 15 & 4 & $60 \mathrm{~s}$ & $\mathrm{M}$ & Accountant (23) & Small urban & 7 \\
\hline 16 & 2 & $50 \mathrm{~s}$ & $\mathrm{~F}$ & Degree (34) & Small urban & 8 \\
\hline 17 & $<1$ & $30 \mathrm{~s}$ & $\mathrm{M}$ & HNC (10) & Small urban & 5 \\
\hline 18 & 1 & $60 \mathrm{~s}$ & $\mathrm{~F}$ & PG Dip (12) & Very urban & 10 \\
\hline 19 & 1 & $50 \mathrm{~s}$ & $\mathrm{~F}$ & PhD (11) & Very urban & 10 \\
\hline
\end{tabular}

SIMD refers to the Scottish Index of Multiple Deprivation (SIMD, 2016). 10 is the most prosperous and 1 the least. 
The interviewees themselves, however, were not representative of the Scottish population as a whole. For example, and all but two were educated to at least degree level or equivalent, and two thirds of them were over 50 years old. It is not possible to state whether or not those in the sample were representative of the community councillor population as a whole because such demographic details are not available. However, it is generally recognised that community council positions are often filled by well-educated older people with interests in, as well as enough free time for, voluntary engagement in community activities. Therefore the demographic profile of those who came forward for interview was not unexpected.

The data collected by interview were analysed manually with reference to the SCONUL pillars, and the six project research questions. This was undertaken by copying responses to questions to a spreadsheet workbook: one row per interview question, one worksheet per interviewee. On each worksheet, columns were created for each pillar and research question. All responses were manually examined for content relevant to the pillars and research questions: such content was copied to the relevant columns. Standard text concatenation was used to collate all relevant content on a 'summary' worksheet: one cell per pillar or research question, thus creating a thematic arrangement of the data for analysis. Collated data were then manually counted, for example to obtain the numbers of interviewees who use Facebook to obtain information. The data were then re-examined for comments exemplifying, for example, issues experienced when attempting to use Facebook.

\section{Findings}

\section{Learning about the community councillor role}

RQ1 was devised to consider the means by which community councillors access and understand information on their duties and rights. The majority of interviewees (14) claimed that they do think consciously about the information that they require to make sense of their roles. One elaborated upon this by explaining that community councillors are also 'reminded of [their] duties and rights, or responsibilities, by the ward members, or members of the public'.

With the exception of just one, all interviewed for this study had either been supplied with a community council scheme (the document written by local authority officials that specifies community councillors' duties and rights), or had access to this information online. They also have the opportunity to engage in training provided by local authorities.

Nine interviewees used means other than local authority provision to determine their roles. Other sources include peers ( 3 mentioned mentoring relationships with more experienced community councillor colleagues) and 'official' web sites such as that of the Scottish Government, and the national Community Council web site. Engagement with this latter set of sources, however, appears to be largely ad hoc.

Although most (16) were aware of their current levels of knowledge of their community councillor roles, there was little evidence of any clear planning to make up for knowledge that is lacking.

\section{Gathering and sharing information about local issues}

The interviewees confirmed that a key duty of the community councillor role is to gather and share information. As one interviewee noted:

'We don't transact actions. We don't have any

financial power. Our currency is information.'

This information sharing is bi-directional: community councillors represent the 'voice of the community' to public authorities, as well as serving as communication channels from public authorities to citizens. They are motivated to do so for the good of those living in their locality. This applies generally, for example, 'to maximise the quality of life for [our] residents', 'to effect positive change', and in respect of initiating action on particular issues such as 'shared spaces or green spaces, traffic... [and] dog-fouling'.

RQ2 was devised to establish the information sources used by community councillors to inform themselves of local issues of relevance to the communities that they serve. The most important source (mentioned by 13 interviewees) is the local authority in which the community council is located. Information on planning applications disseminated by local authorities featured significantly as an interview topic (mentioned by 17 interviewees). This is largely because community councils are statutory consultees on planning applications and, on a weekly basis, automatically receive details of any relevant to their locality. Such official sources are supplemented by information provided by citizens and the local press (each mentioned by 9 interviewees), and discovered on Facebook (mentioned by 6). Other sources include other social media (Twitter and LinkedIn), developers and construction workers (questioned directly about work in progress), contributions to comments boxes, responses to surveys (for example, on traffic), and other local organisations at networking events. Community councillors also make themselves visible presences at local events - some of which are organised by community councils - where they are able to gather local information.

The interviewees reported that the deployment of social media by community councillors to discover local opinion varies from high use (3) to complete avoidance (5). Indeed three interviewees admitted that they do not use social media at all, even as private individuals: one said 'I've just 
avoided it [but] now l'm finding it would probably actually be quite good'.

Four community councillors interviewed for this study have experienced lack of support and/or direct opposition in response to suggestions that Facebook be treated as an information source for community council work. One explained failed attempts to set up a Facebook presence for the community council:

'I said "OK, if you give me your email address, I'II set up [a Facebook page] under [the name of the community council]"... There was a whole kerfuffle about that and they didn't give me their password and email address.'

In two cases it was the community councillors themselves who were not interested in the adoption of Facebook in their roles as representatives, even in the knowledge that many of the citizens that they serve are regular users of social media in general. One declared certain aspects of Facebook 'an outrage', and the other expressed relief at not being obliged to deal with an information source that had encouraged trolling in the past:

The community council had at one time set up a Facebook page, but it was the subject of trolling so they decided it wasn't a good idea. I'm very glad because I don't have to trouble with it. I can't see what the point would be in us setting up as a potential target for abuse.

Another issue reported by two interviewees is difficulty in obtaining relevant information, or information in helpful formats, from their local authorities. In one instance an interviewee was obliged to resort to Freedom of Information requests to access information required.

There was also an indication that community councillors risk information overload in their roles: one interviewee stated that he restricted his information-gathering and related activities to issues either taking place in, or directly affecting, his community council's area. To do otherwise would be to enlarge the unpaid volunteer role to one that is unmanageable.

\section{The dissemination of information from community councillors to members of their communities}

Having considered in RQ2 how community councillors inform themselves, RQ3 is concerned with the means by which community councillors inform others. The channels of communication deployed are listed in Table 3 below.
Table 3: Channels for disseminating information from community councils to citizens

\begin{tabular}{|l|l|}
\hline \multicolumn{2}{|l|}{$\begin{array}{l}\text { Channels for disseminating information from } \\
\text { community councils to citizens }\end{array}$} \\
\hline Digital & Non-digital \\
\hline Email & Newsletters \\
Social media: Facebook, & Local press \\
Twitter, blogs & Noticeboards in \\
& community spaces such as \\
& churches and public \\
& libraries \\
& Word of mouth at events: \\
& e.g. community council \\
& meetings, networking \\
& events, farmers' markets \\
\hline
\end{tabular}

The frequency of use varies from channel to channel. For example, although the majority of interviewees (16) reported the use of the Internet to disseminate information, the use of particular applications is uneven. For example, Twitter is used mainly as a broadcast mechanism to automatically disseminate links to new posts on web sites. Similarly a physical noticeboard in one community is subject to monthly updates, whereas another elsewhere is updated 'fanatically'.

The analysis of data collected for this study revealed that it is rare for community councillors to pay close attention to the evaluation, management and presentation of the information that they disseminate to their citizens using the tools listed above. This indicates that the activities associated with the final three pillars of the SCONUL model of information literacy are not undertaken thoroughly within community councils. Indeed only 3 interviewees stated that they and their colleagues have defined roles to undertake such tasks.

In terms of evaluation, however, the provenance and authority of information are the two criteria that are regularly applied. 'Official' sources such as local authorities, central government, or sources previously assessed as trustworthy are regarded highly. For example, one interviewee highlighted the importance of differentiating between facts and opinions with reference to a controversy over the siting of wind turbines when it 'difficult to gauge... how representative the two sides were of public opinion'.

Clarity in the presentation of information consulted is also regarded as a marker of its quality:

'The clearer it is, the more likely it is to be useful and the more likely we are to say "It's been worthwhile searching that out".'

One interviewee stated that he generally goes as far as checking reported information against the primary sources:

'For example, yesterday the Autumn Statement was reported in the news, so I said "that's interesting". Then I go to read what the chancellor 
actually said on the Treasury website, and read it calmly.'

All but three interviewees demonstrated that understanding the information needs of the citizens that they serve is also important to the role of disseminating information to their communities. However, only 5 made reference to means such as analytics by which they are able to assess these information needs. Furthermore 3 interviewees spoke about difficulties in engaging citizens in the issues that the community councils seek to address. This raises questions regarding extent to which community councillors genuinely appreciate the information needs of those that they are meant to inform.

Two interviewees noted poor leadership and internal communication issues as obstacles to information sharing. One interviewee alluded to the dominance of the chair within the community council in question. Another, who has responsibility for her community council's publicity and Internet communications complained that she has 'no communication whatsoever with the chair and the secretary because they do nothing [visible] between meetings' and this impairs the efficient transmission of information found by her peers to citizens in the area.

\section{Recommendations for the improvement of community councillors' information skills and practices}

The collection and analysis of data for the IL-DEM project provided an opportunity to develop recommendations to improve the information skills and practices of community councillors, as articulated in RQ4.

The majority (11) admitted skills gaps, both at the level of the individual and that of their community councils as collectives. One elaborated on this with mention of a lack of trust in the information skills of other community councillor colleagues.

The most obvious skills gap (highlighted by 4 interviewees) is little or no expertise in social media. Even in cases where social media is in regular use, it is not sophisticated. For example, while metrics such as web site hits and Facebook 'likes' are counted, only a few interviewees (4) serve on community councils that use analytics to understand their audiences.

Other gaps relevant to information skills and practices of community councillors identified in the interviews included digital engagement and data collection and analysis for the purposes of gauging public opinion. Given the findings related above on information needs assessment, training in this would also benefit community councillors.

These findings contribute to two of the main project recommendations that (i) community councillors should lobby for suitable training, and take part in an audit of their information skills and practices, with leadership and support from the Improvement Service; and (ii) community council liaison officers should do more to emphasise the value of information skills in supporting community councils' statutory role of representing citizen opinions.

\section{Public library support of community councils}

Inclusion of RQ5 allowed for an exploration of the role of the Scottish public library services in the work of community councillors. Desk research completed as part of this study revealed that public library provision for community councils is only specified by one local authority in Scotland (City of Edinburgh Council, 2014). In its policy the City of Edinburgh states that libraries can provide community councils with noticeboards, meeting venues and consultation areas, Internet access, telephones and faxes, scanners, guillotines, and free printing and photocopying.

This is not to say that public libraries elsewhere do not support community councillors. Rather, community councillors are not considered separately as a user group with particular needs. Like the rest of the population, community councillors are welcome take advantage of PC access (all 32 local authorities), free wifi (25), printing facilities (22), and hold gatherings in public meeting rooms (9) across the Scotland's public library services. In terms of training, community councillors could also take advantage of provision for the European Computer Driving Licence and other courses. However, this research did not uncover any publicity for training that focuses on improving the information skills and practices of public library users.

The absence of dedicated library support for community councils and their representatives was echoed in the interviews conducted for this study: only three interviewees stated that public libraries do more than provide meeting venues or public access to community council minutes: one interviewee referred to a library that 'currently helps with picture and historical research', another to libraries that 'provide computers, helpful staff, resource open at night', and the third highlighted the library as a 'source of information, but not of training'. Nine interviewees stated explicitly that they did not use public libraries for their community council work. Indeed one emphatically declared 'libraries don't do much for me' because 'everything' is available online - even though this interviewee's community council actually holds all its meetings in a library.

The findings noted here generated the third of the main project recommendations: that and public library services should extend their roles to support community councils. Information literacy training, particularly around social media would be a valuable contribution.

\section{Information literacy and the building and support of citizenship}

RQ6 was designed to assess the extent to which the information literacies of individual community councillors contribute to building and support of citizenship. There 
was general agreement that high levels of information literacy amongst the community councillor population has potential and actual benefits. In a setting where information is the currency, it has to be the 'right' currency:

'you have to be able to know that what you're telling people is correct, therefore if you don't understand or you haven't researched the information, they're not going to get the right answer'.

The examples provided by the interviewees related to the gathering of information as evidence for public enquiries and controversial planning proposals (including pressure for affordable housing), to support local charities, to promote equitable use of 'common good resources', to lobby for the retention of public toilets (without which tourists might bypass certain areas, and thus harm local economies), to make provision for citizens in areas suffering social deprivation, to take part in development of local cycle routes, to make provision for after-school care and child-minding, to tackle environmental issues, to assist citizens who have suffered misfortunes, and to combat democratic deficits in general.

\section{Discussion}

The analysis above has shown that community councillors engage with a range of print, online, and face-to-face information sources and tools as they undertake their duties. Local authority support is the most important to accessing and sharing information between local communities and public authorities.

Some of the findings confirm extant knowledge on community councils, such as difficulties associated in completing tasks with an incomplete 'workforce' (Goodlad et al., 1999; Ryan and Cruickshank 2012; 2014) and Internet engagement (Ryan and Cruickshank, 2014). The high reliance on people as information sources shows the articulation of this work with others that consider workplace information literacy where team work and social interactions are important (Forster, 2017b; Goldstein and Whitworth 2017).

Other significant findings worthy of further consideration relate to social media use, citizen information needs, methods of garnering public opinion, and the role of the public library service in supporting community councils. These are discussed below with a statement on the use of the SCONUL model in research design.

Perhaps the most striking findings from this work are those related to attitudes towards, and adoption of, social media as channels of communication in community council work. Statistics from the first quarter of 2017 indicate that $91 \%$ of the UK population are Internet users (Office for National Statistics, 2017), and in June 2017 it was reported that $76 \%$ of UK adult Internet users have at least one social media profile (Ofcom, 2017, p. 52), with $95 \%$ maintaining a Facebook account (p. 54). The population habitually accesses online public and civic services to: seek information (for example, about tax from the Her Majesty's Revenue and Customs web site); complete processes (for example, passport renewal); pay for local services (for example, parking tickets); and sign petitions or contribute to campaigns (p. 67). Given this ubiquity of Internet use in the UK in general, and of social media in particular, uneven uptake by community councils of platforms such as Facebook for information sharing is notable.

A possible explanation for the cases where there is apparent reluctance towards social media as a tool for community council work is the older age profile of the interviewees, and of the others to whom the interviewees referred in their explanations of non-adoption of social media - assuming that community council membership comprises a high proportion of Internet users aged over 55 who are less likely than average to have a social media account (55-64 59\%; 65-74 48\%; 75+41\%) (Ofcom, 2017, p. 53). In addition, it is worth drawing attention to the means by which community councillors evaluate information sources. They place the greatest emphasis on provenance and authority, i.e. two elements that have traditionally been considered weak in social media environments, and which, since 2016, have attracted greater attention in general due to prominent media discussions of fake news. Trust amongst the population at large in information from social media sources has lessened since 2015 (Ofcom, 2017, p. 111) so this may also be a determinant of the caution around the use of particular platforms here. A third factor at play may be the perceived additional time commitment required for managing social media presences on platforms such as Facebook and Twitter, especially since volunteer representatives often serve on community councils where there is not a full membership complement. Whatever the reasons, community councils that do not have active social media presences are not taking advantage of communication channels that are common tools for information sharing amongst the members of the population that they are mandated to serve.

A second theme that merits further consideration is the community councillors' uncertain understanding of the needs of the communities that they serve. There seems to be an information vacuum here: community councillors are generally aware that they do not fully appreciate the best means for gathering information from citizens to inform their roles as hyperlocal representatives, yet are not proactive in addressing this issue. They therefore risk inefficiency in gauging public opinion and passing this on to public authorities as is required in their roles.

Along with the findings on social media adoption, these conclusions on the extent to which the community councillors truly represent the views of their fellow citizens assume greater significance when the source of data analysed for this project is taken into consideration. It is likely that those who responded to the call for participation in the interviews were amongst those most 
interested in the themes of the study, and belong to a subset of community councillors who are the most selfefficacious and information literate (including individuals who will go to great lengths to track down the information they seek, for example through Freedom of Information requests). Further indication of this is the readiness with which the interviewees criticised the information practices of some of their fellow community councillors. Thus it is highly probable that the findings presented in this paper represent good or best information practice in community councils.

A further issue to highlight is the gap between the espoused ambitions expressed in Ambition and opportunity: a strategy for public libraries (SLIC, 2015) and the perceptions of public library of support exhibited by the community councillor interviewees. Whatever success public libraries have achieved as community information hubs, they are not obviously visible as strong supporters of community councillors and their work.

In terms of research design, the strategy of deploying the SCONUL model of information literacy to inform its development was successful. In addition, it has been possible to consider the information literacy of the community councillors interviewed with reference to the pillars of the SCONUL model. So, for example, the findings related to low use of social media analytics relate to the 'present' pillar, and the allocation of roles (for example to develop a social media strategy, or assign specific members to take responsibility for particular communication channels) relate to the 'manage' pillar. This work could be extended, for example through deeper consideration of the development of the information literacy of individuals (especially those who exhibited high levels) and how this fits with that of the other group members, or by establishing the alignment of the information literacy of community councilors to other models.

\section{Conclusion}

Prior work that considers information practices in government has tended to focus on employees who deliver services (for example, Killick et al., 2016; Tait and Edwards, 2016), and professional politicians such as MPs and MSPs (for example, Auty, 2005; Smith and Webster, 2004). There is also related work on citizens themselves and their 'political' information literacy (for example Smith, 2016). The novelty of the study reported here is found it its consideration of the information literacy of volunteer representatives active at the level hyperlocal government. As well as filling this gap in the literature, the findings noted above will assist in the development of effective community councils in Scotland and similar forms of hyperlocal democracy elsewhere.

This analysis has revealed that community councillors engage with a range of information sources and tools in the course of carrying out their duties. Of these local authority support has the greatest bearing on community councillors' ability to fulfil their roles of accessing and sharing information between local communities and public authorities. In addition, it has been revealed that community councillors access information from a range of other sources, including print, online and face-to-face for dissemination to citizens in their localities.

Uptake of social media in this work is uneven. In some instances they have been embraced, and in others they are considered alongside other tools for information access and dissemination. However, this research has shown that it is not uncommon to find some community councils where the adoption of social media is positively discouraged.

In cases where community councillors are aware of gaps in their knowledge, they are not proactive in addressing them. Similarly they do not appear to have a full appreciation of the information needs of the communities that they serve.

The main recommendations generated from this work are that (i) community councillors should lobby for suitable training, and take part in an audit of their information skills and practices, with leadership and support from the Improvement Service; (ii) community council liaison officers should do more to emphasise the value of information skills in supporting community councils' statutory role of representing citizen opinions; and (iii) that public library services should extend their roles to support community councils.

In addition, while not a focus of this paper, some initial conclusions on the validity of the SCONUL model for information literacy in this particular context can be drawn. Despite the high level of education and selfefficacy of community councillors, their democratic activities are not fully underpinned by information practices in line with the SCONUL 7 pillars. This finding merits further investigation with reference to other extant models of information literacy.

\section{Acknowledgements}

The authors thank the community council liaison officers, Improvement Service staff, and public librarians who willingly supported this study by providing information, helping to pilot interview questions, and recruiting participants. The authors are most grateful to the community councillors who participated in the research.

\section{Funding statement}

The project on which this paper is based was funded by the Information Literacy Group (ILG) of the Chartered Institute of Library and Information Professionals (CILIP).

\section{References}

American Library Association (2000) Information literacy competency standards for higher education. Available at: 
http://www.ala.org/acrl/standards/informationlitera cycompetency\#ildef (accessed 16 July 2017).

Auty C (2005) UK elected representatives and their weblogs: first impressions. Aslib Proceedings 57(4): 338-355.

Banek Zorica M, Spiranec S and Biskupic IO (2014) What is the employers stand on information literacy researching employers on expected generic outcomes. In: Lifelong Learning and Digital Citizenship in the 21st Century (eds S Kurbanoğlu, S Špiranec, E Grassian, D Mizrachi and R Catts), Dubrovnik, Croatia, 20-23 October, pp.673-682. London: Springer.

Bent M and Stubbings R (2011) The SCONUL Seven Pillars of Information Literacy: a research lens for higher education. Available at: https://www.sconul.ac.uk/sites/default/files/docume nts/researchlens.pdf (accessed 16 July 2017).

Bort E, McAlpine R, and Morgan G (2012) The Silent Crisis: Failure and Revival in Local Democracy in Scotland. Report, The Jimmy Reid Foundation, UK, April.

City of Edinburgh Council (2014) Community Councils Library support. Available at: https://www.edinburgh.gov.uk/info/20133/communi ty_planning/731/community_councils_-

_library_support (accessed 16 July 2017).

Cruickshank P, Ryan BM and Smith, CF (2014) Disconnected Democracy? A survey of Scottish Community Councils' online presences. Scottish Affairs 23(4): 486-507.

Dalton M (2013) Developing an evidence-based practice healthcare lens for the SCONUL Seven Pillars of Information Literacy model. Journal of Information Literacy 7(1): 30-43.

Davis JL and Jurgenson N (2014) Context collapse: theorizing context collusions and collisions. Information, Communication \& Society 17(4): 476-485.

Engeström Y. (1987) Learning by expanding: an activitytheoretical approach to developmental research. Helsinki: Orienta-Konsultit.

Forster M (2017a) How is Information Literacy experienced in the workplace? In: Forster M (ed), Information Literacy in the Workplace. London: Facet Publishing, pp.10-28.

Forster M (2017b) Information Literacy and the personal dimension: team players, empowered clients and career development. In: Forster M (ed), Information Literacy in the Workplace. London: Facet Publishing, pp.29-39.
Forster M (2017c) Information Literacy and the Workplace: new concepts, new perspectives?. In: Forster M (ed), Information Literacy in the Workplace. London: Facet Publishing, pp.1-9.

Goldstein S (2015) A graduate employability lens for the SCONUL seven pillars of information literacy. Available at:

http://www.sconul.ac.uk/sites/default/files/documen ts/Employability_Lens_only_2015_0.pdf (accessed 16 July 2017).

Goldstein S and Whitworth A (2017) Determining the value of information literacy for employers. In: Forster M (ed), Information Literacy in the Workplace. London: Facet Publishing, pp.67-84.

Goodlad R, Flint J, Kearns A, Keoghan M, Paddison R and Raco M (1999) The Role and Effectiveness of Community Councils with Regard to Community Consultation. Report for the Commission on Local Government and the Scottish Parliament. June. Edinburgh: The Scottish Office Central Research Unit. Available at: http://www.gov.scot/Resource/Doc/156613/004207 3.pdf (accessed 16 July 2017).

Hall H, Cruickshank P and Ryan BM (2017, in press). Exploring information literacy through the lens of Activity Theory. In: European Conference on Information Literacy. St Malo, France, 18-21 September. London: Springer.

Improvement Service (2015) Community Council Fairer Scotland Event. Report for the Scottish Government. September. Edinburgh: Improvement Service. Available at:

https://khub.net/documents/10440977/0/Communit $\mathrm{y}+$ Council+Fairer+Scotland+Event+Report (accessed 16 July 2017).

Irving C, Brettle A and Hall H (2015) How can information literacy be modelled from a lifelong learning perspective? Available at: www.rgu.ac.uk/file/i3irving-et-al-pdf-800k (accessed 16 July 2017).

Kauhanen-Simanainen A (2005) Collaborative information literacy by government. IFLA Journal 31(2): 183-187.

Killick L, Hall H, Duff A and Deakin, M (2016) The census as an information source in public policy-making. Journal of Information Science, 42(3): 386-395.

Lloyd A (2007) Understanding information literacy in the workplace: Using a constructivist grounded theory approach. In: Lipu S, Williamson K and Lloyd (eds). 
Wagga Wagga: Centre for Information Studies, Charles Sturt University, pp. 68-86.

Lloyd A (2011) Trapped between a Rock and a Hard Place: What Counts as Information Literacy in the Workplace and How Is It Conceptualized? Library Trends, 60(2): 277-296.

Lloyd A (2013) Building information resilient workers: The critical ground of workplace information literacy. What have we learnt? In: Worldwide Commonalities and Challenges in Information Literacy Research and Practice (eds S Kurbanoğlu, E Grassian, D Mizrachi, R Catts and S Špiranec), Istanbul, Turkey, 22-25 October 2013, pp.219-228. London, Springer.

Lloyd A (2017) Learning within for beyond: exploring a workplace information literacy design. In: Forster M (ed), Information Literacy in the Workplace. London: Facet Publishing, pp.97-112.

Mair C (2016) Scottish Local Government: Past, Present and Futures. In: McTavish D (ed), Politics in Scotland. Abingdon: Taylor \& Francis, pp.108-112.

Ofcom (2017) Adults' media use and attitudes. Available at: https://www.ofcom.org.uk/_data/assets/pdf_file/002 0/102755/adults-media-use-attitudes-2017.pdf (accessed 17 July 2017).

Office for National Statistics (2017) Internet users in the UK: 2017. Available at: https://www.ons.gov.uk/businessindustryandtrade/it andinternetindustry/bulletins/internetusers/2017 (accessed 17 July 2017).

Owens MRO (1976) The State Government and Libraries. Library Journal, 101(1): 19-28.

Reedy K, Mallett E and Soma N (2013) iKnow: Information skills in the 21st Century workplace. Library and Information Research, 37(114): 105-122.

Ryan BM and Cruickshank P (2012) Community Councils online. Available at: http://www.iidi.napier.ac.uk/c/publications/publicati onid/13373555 (accessed 16 July 2017).

Ryan BM, and Cruickshank P (2014) Scottish Community Councils online: the 2014 survey. Available at: http://www.iidi.napier.ac.uk/c/publications/publicati onid/13379605 (accessed 16 July 2017).

SCONUL (n.d.) The SCONUL7 Pillars of Information Literacy through a Digital Literacy "lens". Available at: http://www.informationliteracy.org.uk/wp-
content/uploads/2013/01/SCONUL-

digital_literacy_lens_v4.doc (accessed 16 July 2017).

SCONUL (2011) The SCONUL seven pillars of information literacy: core model for higher education. Available at: http://www.sconul.ac.uk/sites/default/files/documen ts/coremodel.pdf (accessed 16 July 2017)

SCONUL (2015) The graduate employability lens on the SCONUL Seven Pillars of Information Literacy. Available at:

https://www.sconul.ac.uk/sites/default/files/docume nts/Employability_Lens_only_2015_0.pdf (accessed 16 July 2017).

SCONUL (2016) SCONUL 7 Pillars through an Open Content "lens". Available at: http://www.sconul.ac.uk/sites/default/files/documen ts/OER_lens.pdf (accessed 16 July 2017).

Secker J, Coonan E, Webster H and Wrathall K (2016) ANCIL in practice. Available at: https://newcurriculum.wordpress.com/usingancil/ancil-in-practice (accessed 16 July 2017).

SIMD (2016) Scottish Index of Multiple Deprivation. Available at: http://simd.scot/2016 (accessed 16 July 2017).

Skoric MM, Zhu Q, Goh D and Pang N (2015) Social media and citizen engagement: A meta-analytic review. New Media \& Society 18(9): 1817-1839.

SLIC (2015) Ambition \& Opportunity: A Strategy for Public Libraries in Scotland 2015-2020. Available at: http://scottishlibraries.org/media/1133/ambitionopportunity-scotlands-national-public-librarystrategy.pdf (accessed 16 July 2017).

Smith CF and Webster CWR (2004) Members of the Scottish Parliament on the net. Information Polity, 9(1/2): 6780.

Smith L (2016) School libraries, political information and information literacy provision: findings from a Scottish study. Journal of Information Literacy 10(2): 2-25.

Tait E and Edwards R (2016) Information literacy and information seeking of public sector managers in the Welsh Government. Library and Information Research 40(123): 88-105.

UK Government (1973). Local Government (Scotland) Act 1973. Available at: http://www.legislation.gov.uk/ukpga/1973/65/pdfs/ ukpga_19730065_en.pdf (accessed 16 July 2017). 
Manuscript of paper accepted by Journal of Librarianship and Information Science for publication in 2018

Wilson T (2006) A re-examination of information seeking behaviour in the context of activity theory. Information Research, 11(4): paper 260.
Wilson T (2008) Activity Theory and Information Seeking. Annual Review of Information Science and Technology 42(1): 119-161. 